Instructions for authors, subscriptions and further details:

http://qre.hipatiapress.com

\title{
Engaging in Narrative Inquiries with Children and Youth, by Jean Clandinin, Vera Caine, Sean Lessard and Janice Huber
}

André Freitas ${ }^{1}$

1) Centre for Research and Intervention in Education, University of Porto, Portugal.

Date of publication: October $28^{\text {th }}, 2019$

Edition period: October 2019 - February 2020

To cite this review: Freitas, A. (2019). Engaging in Narrative Inquiries with Children and Youth [Book Review]. Qualitative Research in Education, 8(3), 378-380. doi:10.17583.qre.2019.4813

To link this review: http://dx.doi.org/10.17583.qre.2019.4813

PLEASE SCROLL DOWN FOR ARTICLE

The terms and conditions of use are related to the Open Journal System and to Creative Commons Attribution License (CC-BY). 


\section{Review I}

Clandinin, J., Caine, V., Lessard, S., \& Huber, J. (2016). Engaging in narrative inquiries with children and youth. New York: Routledge. ISBN: 978-1-62958-219-1

Having the conviction of narrative inquiry to be a valid and guaranteed methodological approach for the design and progress of research in Education means being aware of Clandinin and her team's work. The authors begin their book - way more than a text book - by highlighting the methodology as a relational research. Along the book, the authors share personal experiences careful and intentionally selected to discuss the phenomenon of narrative. With the intention to deepen knowledge on various forms narrative enquiries may have as well as the elements necessary to engage in the methodological approach, the book present its definitions; highlights ontological commitments; and includes specific debates. We find 14 detailed chapters that discuss the processes from shaping the conception of "experience" to finding participants and writing narratives with them - not necessarily in that order.

When objectivity is not what the researcher is aiming to achieve an allnew world of opportunities arise. Imagining the possibilities that narrative inquiry allows to the field of education and to the educational research improve more than the methodological theory - increase the researcher. The multiple stories that a person live - where the inquirer is included - it is the starting point for understanding how to shape the research - aware of multiples dimensions such as the 'landscape' that involve the temporality, place and the relations in between. Focused in the engaging with children and young people this book is a ex-libris. Doing research with - not about children and youth requires us to prepare our heart for powerful emotions.

"Narrative inquiry, the study of experience understood narratively, means much more than telling stories, more than living stories" (p. 15), it 
means being part of the stories that are being told and lived. With children and young people, this conception is even more visible and may be particularly present in the inquirers. In chapters 3 and 4 the authors emphasize being part and participating in the 'puzzle' that is being constructed during the research. In the two following chapters, the authors discuss about how to find participants. As the participants of the research are children and young people, the ethical relation founded with the inquirers during the negotiations is permeated by vulnerabilities. In institutional contexts like schools and hospitals researchers have possibilities to find participants who may consent participating in the research. The process to involve participants that are part of those institutions is initiated by the board approval followed by the approval of the children's families. When the participants are from outside institutional contexts, the first communications with children and families is more direct. Finding participants is an ongoing negotiation. In the $7^{\text {th }}$ chapter the interactions between children and youth and researchers are problematized. The way participants shape their stories affect the inquiries. The chapter puts in perspective the ways that narrative inquiries create ripples into lives. The following chapter (8) focuses on the discussion about the interaction between the adult as researcher and the child, referring to the term alongside as the central point of the implication between them when in the field within familial contexts. In the chapters 9 and 10 the authors explore the co-composing materials that are fundamental parts of the research. The involvement of young participants requires approaches that are sensitive to their symbolic worlds. The $11^{\text {th }}$ chapter is the moment of the book where the reader can feel from another point of view the way that D. Jean Clandinin, Vera Caine, Sean Lessard and Janice Huber show their research method. From the Donovan narrative, they show an example of a narrative that was co-constructed. In chapter number 12 the discussion concerns children and youth's experiences represented by adults as inquiries. It may be often in previous investigations to refer to children as vulnerable participants. Therefore, there is the idea of someone needing to speak on their behalf. The authors note that everybody may be vulnerable and the focus of the concerns must be centred in the moral and ethical considerations for the best comprehension of children and youth's stories. In chapter number 13, the authors addressed the principal ideas and key concepts that they have developed in the book. Specifically, the relation and 
ethical responsibilities of narrative inquiries; the narrative inquiries being in the midst of the research and in the researcher's own personal ongoing life's; the negotiation entry to the field; the constant and continued inquire of the researcher's experiences; the negotiation of relationships; the process from field to field texts and then to interim texts and the final research texts; the relation response communities; and the personal, practical and social justification as social sciences researcher's where they express their commitment to understanding lives always in the making. In the last chapter they highlighted the attention to relational ethics at work.

This book open news perspectives on how to address the narrative inquiry to educational research mainly in the senses attributed in terms that have been noticed in literature with their conventional terminologies. The necessary reinterpretation in the light of the recent and creative scientific research is a statement of what is the essence of narrative inquiry: to be aware of others and ourselves. This book it is a recommended guideline for beginners and experts in the area.

* Special thank you to the children that shared life with me.

André Freitas

University of Porto andrefreitas@fpce.up.pt 